Jurnal Akuntansi \& Perpajakan, Volume 2, No. 1, Juli 2020

\title{
STRATEGY OF SMEs IN THE COVID-19 PANDEMIC PERIOD
}

\author{
Agustina Prativi Nugraheni ${ }^{1}$, Octavia Lhaksmi Pramudyastuti ${ }^{2}$, Suci Nasehati Sunaningsih ${ }^{3}$ \\ Universitas Tidar
}

\begin{abstract}
The covid-19 pandemic that is happening right now has a global impact. In the field of economy, this pandemic cause consumer purchasing power has declined. The decline in consumer purchasing power can result in businesses experiencing a turn over and even closing down. Facing this covid-19 strategy is needed to be able to sustain the business. This study aims to analyze the strategies carried out by SMEs during the pancemic. This research is a qualitative research with a case study approach. The research data obtained through surveys and respondents in this study were 33 SMEs in the field of crafts in Solo. The results showed that SMEs had implemented a strategy that included improving product quality, improving service quality and utilizing technology.
\end{abstract}

Keywords: covid-19, strategy, SME

\section{STRATEGI PELAKU UMKM PADA MASA PANDEMI COVID-19}

\begin{abstract}
ABSTRAK
Pandemi covid-19 yang terjadi saat ini sangat berdampak secara global. Dalam bidang perekonomian pandemic ini menyebabkan turunnya daya beli konsumen. Turunnya daya beli konsumen dapat mengakibatkan pelaku usaha mengalami penurunan omset bahkan gulung tikar. Menghadapi covid-19 ini diperlukan strategi untuk dapat mempertahankan usaha. Penelitian ini bertujuan menganalisis strategi yang dilakukan UMKM selama pandemic covid-19. Penelitian ini merupakan penelitian kualitatif dengan pendekatan studi kasus. Data penelitian diperoleh melalui survey dan responden dalam penelitian ini adalah sejumlah 33 UMKM di bidang kerajinan di Solo. Hasil penelitian menunjukkan bahwa pelaku UMKM telah menerapkan strategi yang meliputi perbaikan kualitas produk, perbaikan kualitas layanan dan pemanfaatan teknologi.
\end{abstract}

Kata-kata Kunci: covid-19, strategi, UMKM

Korespondensi: Agustina Prativi Nugraheni, SPd., M.Si. Universitas Tidar. Jl Kapten Suparman 39, Tuguran, Magelang, 56116. Email: devi.agustina@untidar.ac.id 
Jurnal Akuntansi \& Perpajakan, Volume 2, No. 1, Juli 2020

\section{PENDAHULUAN}

Dampak covid-19 dari segi ekonomi dapat mengancam adanya krisis ekonomi secara besar. Hal ini diindikasikan dari aktivitas produksi berhenti, daya beli masyarakat menurun, jatuhnya bursa saham yang mengarah kepada ketidakpastian (Pakpahan, 2020). Secara ekonomi Indonesia juga mengalami kerugian nasional. Kerugian nasional dapat dihitung salah satunya menggunakan acuan Produk Domestik Bruto (PDB) yang merupakan akumulasi total produksi negara dalam jangka waktu satu tahun (Hadiwardoyo, 2020).

Pandemi Covid-19 yang terjadi berdampak pada banyak bidang. Beberapa bidang mengalami kerugian namun ada bidang tertentu yang mengalami keuntungan dari adanya pembatasan social selama pandemic. Bidang yang dapat berpotensi untuk mendapatkan keuntungan dari adanya pembatasan social antara lain bidang kesehatan, operator seluler dan internet provider, asuransi kesehatan dan layanan pengiriman barang (Hadiwardoyo, 2020). Namun ada bidang lain yang mengalami kerugian bidang yang terdampak pandemic covid-19 di Indonesia yaitu pariwisata, investasi dan perdagangan (Pakpahan, 2020).

Pada bidang pariwisata Indonesia terdampak pandemic covid karena mengalami penurunan kedatangan wisatawan. Perhotelan juga mengalami penurunan tingkat hunian Dampak pada bidang investasi ditunjukkan melalui melemahnya harga saham di seluruh dunia. Menyusul tren penurunan tersebut Indeks Harga Saham Gabungan (IHSG) melemah bahkan sebelum Indonesia mengkonfirmasi covid-19 untuk pertama kalinya. Selanjutnya pada 12 Maret saat WHO mengumumkan pandemic, IHSG jatuh 4,2 persen menjadi 4.937. Menindaklanjuti itu perdagangan saham juga dihentikan untuk pertama kalinya sejak 2008 pada tanggal 13 Maret karena pandemic (Soetjipto, 2020).

Bidang perdagangan di Indonesia didominasi oleh Usaha Mikro Kecil dan Menengah (UMKM). UMKM di dalam perekonomian Indonesia merupakan kelompok yang berjumlah paling besar dan juga terbukti tahan dari berbagai krisi ekonomi (Sudayanto, Ragimun, dan Rahma, 2013). Namun pada saat adanya pandemic covid-19 UMKM juga terkena dampak dari pandemi ini. Menteri Koperasi dan UMKM Teten Masduki menyatakan bahwa berdasarkan hasil survey yang dilakukan pandemi covid-19 memberikan dampak besar terhadap keberlangsungan UMKM (Cahyani, 2020). Sebanyak 47 persen UMKM harus gulung tikar karena terdampak pandemic covid-19. Keberlangsungan usaha kecil dan menengah juga terdampak dengan adanya pandemic ini. UMKM mengalami masalah kesehatan arus kas dan pelemahan dari sisi permintaan yang menekan keberlangsungan UMKM.

Berdasarkan survey sebanyak $96 \%$ pelaku UMKM mengalami dampak covid terhadap proses bisnis. Dan sebanyak $75 \%$ mengalami 
Jurnal Akuntansi \& Perpajakan, Volume 2, No. 1, Juli 2020

penurunan penjualan yang signifikan. Dampak pandemic pada UMKM yaitu turunnya kinerja dari sisi konsumsi dan daya beli masyarakat. Menurut Kemenkop dengan adanya pandemic terdapat 56\% UMKM mengalami penurunan penjualan, $22 \%$ mengalami permasalahan pembiayaan, 15\% mengalami masalah dalam distribusi barang dan $4 \%$ mengalami kesulitan untuk mendapatkan bahan baku mentah.

Beberapa bidang ada yang mengalami kerugian dan ada yang mengalami keuntungan selama adanya pandemic covid 19. Pada UMKM yang terbagi di beberapa sector yang berbeda juga merasakan dampak dari covid 19. Oleh karena itu UMKM perlu melakukan strategi untuk tetap mempertahankan keberlanjutan usaha selama pandemic dan tetap eksis setelah pandemi covid-19 ini berakhir. Penelitian ini bertujuan untuk menganalisis strategi yang dilakukan UMKM untuk mempertahankan keberlangsungan usahanya.

\section{KAJIAN TEORI}

\section{Usaha Mikro Kecil Menengah (UMKM)}

Pengertian UMKM menurut Undang-Undang No 20 Pasal 1 Tahun 2008 (Indonesia, 2008)adalah sebagai berikut:

1) Usaha Mikro adalah usaha produktif milik orang perorangan dan/atau badan usaha perorangan yang memenuhi kriteria Usaha Mikro sebagaimana diatur dalam UndangUndang ini
2) Usaha Kecil adalag usaha ekonomi produktif yang berdiri sendiri, yang dilakukan oleh borang perorangan atau badan usaha yang bukan merupakan anak perusahaan atau bukan cabang perusahaan yang dimiliki, dikuasai, atau menjadi bagian baik langsung maupun tidak langsung dari Usaha menengah atau Usaha Besar yang memenugi kriteria usaga Usaha Kecil sebagaimana dimaksud dalam Undang-Undang ini

3) Usaha Menengah adalah usaha ekonomi produktif yang berdisi sendiri, yang dilakukan oleh orang perorangan atau badan usaha yang bukan merupakan anak perusahaan atau cabang perusahaan yang dimiliki, dikuaiasi, atau menjadia bagian baik langsung maupun tidak langsung dengan Suaha Kecil atau Usaha Besar dengan jumlah kekayaan bersih atau hasil penjualan tahunan sebagaimana diatur dalam Undang-Undang ini

4) Usaha Besar adalah usaha ekonomi produktif yang dilakukan oleh badan usaha dengan jumlah kekayaans bersih atau hasil penjualan tahunan lebih besar dari Usaha Menengah, yang meliputi usaha nasional milik negara atau swasta, usaha patungan, dan usaha asing yang melakukan kegiatan ekonomi di Indonesia 
Jurnal Akuntansi \& Perpajakan, Volume 2, No. 1, Juli 2020

Kriteria UMKM menurut Pasal 6 UndangUndang No 20 Tahun 2008 dalam bentuk permodalan adalah sebagai berikut:

\begin{tabular}{|l|l|l|l|}
\hline \multirow{2}{*}{ No } & \multirow{2}{*}{ Usaha } & \multicolumn{2}{|c|}{ Kriteria } \\
\cline { 3 - 4 } & & \multicolumn{1}{|c|}{ Asset } & \multicolumn{1}{|c|}{ Omset } \\
\hline 1 & Usaha & Maks 50 & Maks 300 \\
& Mikro & Juta & Juta \\
\hline 2 & Usaha Kecil & $>50$ Juta- & $>300$ Juta- \\
& & 500 Juta & 2,5 Miliar \\
\hline 3 & Usaha & $\begin{array}{l}>500 \\
\text { Juta- 10 } \\
\text { Menengah }\end{array}$ & $\begin{array}{l}\text { Miliar- 50 } \\
\text { Miliar }\end{array}$ \\
\hline
\end{tabular}

\section{Strategi UMKM}

Beberapa strategi yang dapat dilakukan oleh pelaku UMKM untuk mempertahankan usahanya dalam menghadapi pandemic covid-19 (Hardilawati, 2020):

\section{1) E-commerce}

Melalui e-commerce hambatan penjualan produk dari sisi jangkauan penjualan dapat dihilangkan. Pelaku UMKM dapat memanfaatkan ini untuk memperluas pangsa pasar serta membangun hubungan menggunakan system pemasaran yang optimal.

2) Digital Marketing

Agar pemasaran lebih efektif maka pelaku UMKM perlu selalu belajar memanfaatkan teknologi. Pemilihan media yang digunakan serta menentukan cara komunikasi yang tepat diperlukan agar dapat sesuai dengan pangsa pasar.
3) Perbaikan Kualitas Produk dan Pelayanan Pelaku UMKM perlu meningkatkan pelayanan konsumen selain perbaikan kualitas produk. Peningkatan pelayanan konsumen dapat dilakukan dengan menyediakan layanan pembelian dan juga pengiriman secara online. Hal ini dilakukan agar membentuk kepuasan dan loyalitas konsumen.

4) Customer Relationship Marketing (CRM) CRM atau hubungan pemasaran dengan pelanggan diperlukan untuk menciptakan loyalitas konsumen. Loyalitas konsumen dapat dicapai saat konsumen puas dan pelaku UMKM tetap mempertahankan hubungan dengan konsumen. Hal ini dilakukan sehingga dapat terjadi transaksi pembelian dari konsumen secara berulang.

Selain strategi di atas, UMKM juga dapat melakukan strategi berikut untuk mempertahankan usahanya (Setiono, 2020). Strategi tersebut antara lain:

1) Memperbaiki kualitas produk dan layanan Perbaikan kualitas produk dan layanan diperlukan dengan melakukan pengembangan strategi penawaran produk. Pengembangan produk dan strategi penawaran ini perlu memperhatikan sudut pandang konsumen. Selain memperhatikan konsumen, perlu juga untuk memperhatikan tim atau mitra. Dalam berkoordinasi dan melakukan kolaborasi 
Jurnal Akuntansi \& Perpajakan, Volume 2, No. 1, Juli 2020

dengan tim atau mitra juga diperlukan perbaikan strategi.

2) Memanfaatkan teknologi dengan optimal Pelaku UMKM perlu memanfaatkan teknologi sehingga proses bisnisnya dapat efektif dan efisien. Dalam pemasaran dapat memanfaatkan jejaring social atau sering disebut digital marketing.

3) Mempersiapkan bisnis untuk lebih berkembang

Persiapan bisnis untuk lebih berkembang diimbangi dengan meningkatkan kemampuan pelaku UMKM. Dalam hal pemasaran dapat dioptimalkan melalui e-commerce sehingga saat pandemic sudah usai bisnis dapat berjalan lebih optimal.

\section{METODE}

Penelitian ini adalah penelitian kualitatif menggunakan pendekatan studi kasus. Pengumpulan data penelitian menggunakan data primer melalui survey penelitian. Data penelitian diperoleh melalui survey yang dibagikan kepada UMKM yang bergerak di bidang kerajinan di Solo sebanyak 33 partisipan. Analisis data dilakukan dengan melakukan analisis deskriptif dan menarik kesumpulan hasil penelitian.

\section{HASIL DAN PEMBAHASAN}

Menurut Undang-Undang Nomor 20 Tahun 2008 tentang Usaha Mikro Kecil dan Menengah (UMKM) terdapat beberapa kriteria untuk mendefinisikan pengertian dan kriteria UMKM. UMKM digolongkan berdasarkan jumlah asset dan omset yang dimiliki sebuah usaha. Usaha mikro dengan kriteria yaitu asset maksimal dari usaha 50 juta dan omset maksimal 300 juta. Usaha kecil dengan kriteria yaitu asset usaha 50 juta sampai dengan 500 juta dan omset 300 juta sampai 2,5 miliar. Dan usaha menengah 500 juta sampai 10 miliar dan omset 2,5 miliar sampai 50 miliar.

UMKM merupakan kelompok usaha yang berjumlah paling besar di Indonesia dan terbukti tahan terhadap berbagai macam goncangan krisis ekonomi. Berkembangnya UMKM di Indonesia selama ini didorong oleh beberapa faktor. Faktor pendorong tersebut antaranya adalah pemanfaatan sarana teknologi, informasi dan komunikasi, kemudahan peminjaman modal usaha dan menurunnya tarif $\mathrm{PPh}$ final atau pajak UMKM (Soetjipto, 2020).

Beberapa strategi perlu dilakukan oleh pelaku usaha UMKM untuk mempertahankan keberlangsungan usaha. Strategi UMKM untuk menjaga keberlangsungan usaha sangat diperlukan dalam menghadapi krisi pada saat pandemic covid -19. Ada beberapa hal yang dapat dilakukan UMKM sebagai solusi dalam mempertahankan keberlangsungan usahanya. Hal yang perlu dilakukan antara lain, memperbaiki kualitas produk dan layanan serta memanfaatkan teknologi. Selain itu UMKM juga perlu memperbaiki strategi dalam berkoordinasi dan berkolaborasi dengan tim. Untuk pemanfaatan teknologi bisa dioptimalkan untuk 
Jurnal Akuntansi \& Perpajakan, Volume 2, No. 1, Juli 2020

marketing dan penjualan secara online (Hermansah, 2020).

Strategi bertahan UMKM dapat dibagi menjadi beberapa hal antara lain melalui $e$ commerce, digital marketing, perbaikan kualitas produk dan pelayanan serta customer relationship marketing (Hardilawati, 2020). Pelaksanaan bisnis dengan memanfaatkan teknologi informasi atau sering disebut e-commerce memberikan kemudahan fleksibilitas dalam produksi, memungkinkan dan menerima penawaran dengan lebih cepat (Sudayanto, Ragimun, dan Rahma, 2013).

Pelaku UMKM melakukan beberapa strategi untuk mempertahankan keberlangsungan usahanya selama pandemic covid-19. Beberapa strategi yang dilakukan oleh pelaku UMKM dibagi menjadi tiga strategi yaitu perbaikan kualitas produk, perbaikan kualitas layanan dan pemanfaatan teknologi. Berikut merupakan strategi yang dilakukan oleh pelaku UMKM untuk menghadapi pandemic covid-19:

1) Perbaikan kualitas produk

Hal yang dilakukan oleh pelaku UMKM untuk mempertahankan usahanya adalah dengan memperbaiki kualitas produk. Perbaikan kualitas produk ini dilakukan dengan mengutamakan konsumen, yaitu produk dan usaha lebih berfokus pada konsumen. Selanjutnya inovasi dan kreasi juga dilakukan untuk menjaga kelangsungan usaha. Produk yang diproduksi juga mengkuti permintaan konsumen. Selama pandemic mereka mempertahankan usaha mereka dengan berinovasi mengikuti permintaan konsumen. Usaha lain yang mereka lakukan atau produk lain yang diminati konsumen antara lain masker dan usaha makanan. Namun produk baru ini juga tidak lebih tinggi dari penjualan produk lama. Hal ini dikarenakan selama pandemi daya beli masyarakat juga mengalami penurunan.

2) Perbaikan kualitas layanan

Selain memperhatikan konsumen, perlu juga untuk memperhatikan tim atau mitra. Berdasarkan survey yang dilakukan, para pelaku UMKM menjaga hubungan baik dengan mitra. Hubungan baik dengan mitra antara lain dengan supplier dan distributor. Para pelaku UMKM juga merasa bahwa kolaborasi dengan mitra diperlukan untuk perkembangan usaha mereka. Kolaborasi dengan mitra juga bisa dimanfaatkan untuk mendapatkan ide baru dan saat usaha memerlukan bantuan. Untuk memperluas jejaring usaha dilakukan dengan berhimpun dengan organisasi dengan UMKM dalam bidang serupa.

3) Memanfaatkan Teknologi

Penjualan secara online dan pemasaran secara online merupakan bentuk dari pemanfaatan teknologi. Melalui $e$ commerce dapat tercipta pasar digital baru dengan kemudahan akses, lebih transparan 
Jurnal Akuntansi \& Perpajakan, Volume 2, No. 1, Juli 2020

dan pasar global dengan perdagangan yang efisien Beberapa e-commerce yang dapat dimanfaatkan di Indonesia antara lain shopee, tokopedia, buka lapak, OLX, gojek, lazada dan sejenisnya. E-commerce memiliki pengaruh terhadap peningkatan kinerja UMKM yaitu dengan pengurangan biaya transaksi dan koordinasi aktifikas ekonomi antara rekan bisnis (Hanum \& Sinarasri, 2017). Rata-rata pelaku UMKM juga memanfaatkan teknologi untuk penjualan mereka. Mereka juga memberikan pelayanan penjualan secara online.

\section{KESIMPULAN}

Berdasarkan penelitian yang dilakukan maka diperoleh kesimpulan bahwa pelaku UMKM melakukan beberapa strategi untuk mempertahankan keberlangsungan usahanya selama pandemi covid-19. Beberapa strategi yang dilakukan oleh pelaku UMKM dibagi menjadi tiga strategi yaitu perbaikan kualitas produk, perbaikan kualitas layanan dan pemanfaatan teknologi

Perbaikan kualitas produk yang dilakukan oleh pelaku UMKM untuk mempertahankan usahanya adalah dengan dengan mengutamakan konsumen. Produk dan usaha lebih berfokus pada konsumen. Inovasi dan kreasi juga dilakukan untuk menjaga kelangsungan usaha. Selama pandemic mereka mempertahankan usaha mereka dengan berinovasi mengikuti permintaan konsumen.
Perbaikan kualitas layanan yang dilakukan para pelaku UMKM yaitu menjaga hubungan baik dengan mitra. Hubungan baik dengan mitra antara lain dengan supplier dan distributor. Para pelaku UMKM juga merasa bahwa kolaborasi dengan mitra diperlukan untuk perkembangan usaha mereka. Kolaborasi dengan mitra juga bisa dimanfaatkan untuk mendapatkan ide baru dan saat usaha memerlukan bantuan. Untuk memperluas jejaring usaha dilakukan dengan berhimpun dengan organisasi dengan UMKM dalam bidang serupa.

Pemanfaatan teknologiyang dilakukan oleh pelaku UMKM yaitu melakukan penjualan dan pemasaran secara online. Rata-rata pelaku UMKM juga memanfaatkan teknologi untuk penjualan mereka. Mereka juga memberikan pelayanan penjualan secara online.

Penelitian ini memiliki kekurangan yaitu responden pelaku UMKM hanya dari satu bidang yaitu kerajinan di wilayah Solo. Sehingga mungkin akan berbeda kondisinya untuk pelaku UMKM di wilayah lain dan di bidang UMKM lain. Diharapkan penelitian selanjutnya dapat melakukan penelitian dengan bidang dan wilayah UMKM yang berbeda.

\section{DAFTAR PUSTAKA}

Cahyani, D. R. (2020). 47 Persen UMKM Bangkrut Akibat Pandemi Corona. Tempo. https://bisnis.tempo.co/read/1344540/47persen-umkm-bangkrut-akibat-pandemicorona/full\&view $=$ ok

Hadiwardoyo, W. (2020). Kerugian Ekonomi Nasional Akibat Pandemi Covid-19. 
Jurnal Akuntansi \& Perpajakan, Volume 2, No. 1, Juli 2020

Baskara: Journal of Business and

Entrepreneurship, 2(2), 83-92.

Hanum, A. N., \& Sinarasri, A. (2017). Analisis faktor-faktor yang mempengaruhi adopsi e commerce dan pengaruhnya terhadap kinerja umkm (studi kasus umkm di wilayah kota semarang). Maksimum, Vol. 1(No. 1), 1-15.

Hardilawati, W. L. (2020). Strategi Bertahan UMKM di Tengah Pandemi Covid-19. Jurnal Akuntansi \& Ekonomika, 1(1).

Hermansah. (2020). Simak Strategi Bertahan Bagi UKM hadapi krisis akibat Covid-19. Alinea. https://www.alinea.id/bisnis/strategibertahan-bagi-ukm-hadapi-krisis-akibatcovid-19-b1ZLs9tpp

Indonesia, R. (2008). Undang-Undang Tentang Usaha Mikro Kecil Menengah. In UU No. 20 Tahun 2008.

Pakpahan, A. K. (2020). Covid-19 Dan Implikasi Bagi Usaha Mikro, Kecil, Dan Menengah. JIHI: Jurnal Ilmu Hubungan Internasional, 20(April), 2-6.

Setiono, B. A. (2020). Strategi Bertahan Bagi UMKM Hadapi Krisis Akibat Covid-19. DOAP Universitas Hang Tuah.

Soetjipto, N. (2020). Ketahanan UMKM Jawa Timur Melintasi Pandemi Covid-19. KMedia.

Sudayanto, Ragimun, dan Rahma, R. (2013). Starategi Pemberdayaan UMKM

Menghadapi Pasar Bebas ASEAN. 1. 